Article

\title{
Performance and Emissions of a Spark Ignition Engine Operated with Gasoline Supplemented with Pyrogasoline and Ethanol
}

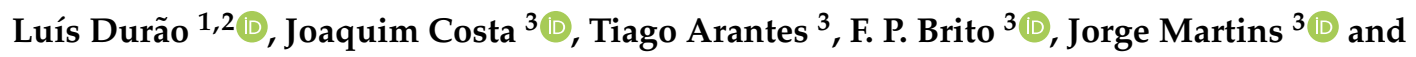 \\ Margarida Gonçalves 1,2,* \\ 1 MEtRICs-Science and Technology of Biomass Department, Faculty of Science and Technology, \\ Universidade NOVA de Lisboa, 2825-149 Caparica, Portugal; luisdurao@gmail.com \\ 2 VALORIZA-Research Centre for Endogenous Resource Valorization, Instituto Politécnico de Portalegre, \\ 7300-110 Portalegre, Portugal \\ 3 MEtRICs-Mechanical Engineering Department, Universidade do Minho, 4800-058 Guimarães, Portugal; \\ joaquimdacosta77@yahoo.com (J.C.); a59846@alumni.uminho.pt (T.A.); francisco@dem.uminho.pt (F.P.B.); \\ jmartins@dem.uminho.pt (J.M.) \\ * Correspondence: mmpg@fct.unl.pt
}

Received: 13 August 2020; Accepted: 3 September 2020; Published: 8 September 2020

\begin{abstract}
The partial replacement of fossil fuels by biofuels contributes to a reduction of $\mathrm{CO}_{2}$ emissions, alleviating the greenhouse effect and climate changes. Furthermore, fuels produced from waste biomass materials have no impact on agricultural land use and reduce deposition of such wastes in landfills. In this paper we evaluate the addition of pyrolysis biogasoline (pyrogasoline) as an additive for fossil gasoline. Pyrogasoline was produced from used cooking oils unfit to produce biodiesel. This study was based on a set of engine tests using binary and ternary mixtures of gasoline with $0,2.5$, and 5\% pyrogasoline and ethanol. The use of ternary blends of gasoline and two different biofuels was tested with the purpose of achieving optimal combustion conditions and lower emissions, taking advantage of synergistic effects due to the different properties and chemical compositions of those biofuels. The tests were performed on a spark-ignition engine, operated at full load (100\% throttle, or WOT-wide open throttle) between 2000 and $6000 \mathrm{rpm}$, while recording engine performance and exhaust gases pollutants data. Binary mixtures with pyrogasoline did not improve or worsen the engine's performance, but the ternary mixtures (gasoline + pyrogasoline + ethanol) positively improved the engine's performance with torque gains between 0.8 and $3.1 \%$ compared to gasoline. All fuels presented $\mathrm{CO}$ and unburned hydrocarbons emissions below those produced by this type of engine operated under normal (fossil) gasoline. On the other hand, $\mathrm{NO}_{\mathrm{x}}$ emissions from oxygenated fuels had contradictory behaviour compared to gasoline. If we consider the gains achieved by the torque with the ternary mixtures and reductions in polluting emissions obtained by mixtures with pyrogasoline, a future for this fuel can be foreseen as a partial replacement of fossil gasoline.
\end{abstract}

Keywords: lipid bio-oils; pyrogasoline; performance; exhaust emissions and spark-ignition engine

\section{Introduction}

Throughout the world, cars are essential in everyday life and related industries, and are a source of jobs and economic growth. Internal combustion engines will continue to be the main means of propelling cars. In the current phase of transition to sustainable mobility, good energetic performance and minimum emissions are critical. In 2050 more than half of the passenger vehicles sold are expected to continue to be equipped with spark-ignition (SI) engines (gasoline, compressed natural gas/liquid 
petroleum gases (CNG/LPG), and gasoline hybrids) [1]. $\mathrm{CO}_{2}$ emissions (the main greenhouse gas (GHG)), which are ubiquitous in combustion engines, are related to fossil fuel consumption [2].

Concerning $\mathrm{CO}_{2}$ emissions, biofuels tend to be neutral and can be used in mixed or pure form in engines. The incorporation of biofuels will allow vehicles to achieve significant reductions in emissions of some pollutants and GHG [3], but it is not feasible to replace all fossil fuel consumption with them [4], with the exception of in Brazil [5]. However, the European Commission [6] introduced the term indirect land use change (ILUC) to account for the consequences on the land use (sustainability) in the production of biofuels. Therefore, the use of waste biomass materials as feedstocks for bioenergy and biofuels is promoted in the European Union as a tool for reducing the deposition of such materials in landfills and of increasing the production advanced biofuels. The Annex IX of the Directive (EU) 2018/2001 lists a group of waste biomass materials (including used cooking oils) whose contribution for the renewable energy shares may be considered to be twice their energy content [7]. On the other hand, changes in consumption patterns have also led to massive waste generation [8]. Many wastes have no economic value and cause environmental problems because of their disposal; that is the case with lipid wastes, such as used cooking oils or animal fats unfit for biodiesel production, that often are disposed of without any kind of material or energetic valorisation [9]. Pyrolysis is a thermochemical process that allows conversion of low-quality lipid wastes into carbon-rich bio-oils that may then be distilled or upgraded to yield advanced biofuels appropriate for replacement of gasoline or diesel.

During pyrolysis, triglycerides (which are the main components of the lipid wastes) undergo cracking and condensation reactions to yield the pyrolysis bio-oil, a mixture of compounds consisting mainly of hydrocarbons, oxygenated compounds, some gaseous products $\left(\mathrm{CO}, \mathrm{CO}_{2}\right.$, and water), and a carbonaceous residue containing the mineral components of the wastes and some high molecular weight organic products [10].

The process temperature and residence time influence the pyrolysis reactions, affecting product yield and composition, but further selectivity may be achieved using modified atmospheres and different types of catalysts [11,12]. It was observed that zeolites were suitable catalysts for the cracking processes of vegetable oils to obtain compounds with boiling points in the range of gasoline [13].

The use of gasoline with added alcohol is a practical way of improving the octane number (ON) of conventional gasoline [14], often used in motor sports. The latent heat of vaporization of ethanol is 2.5 times higher than that of gasoline, allowing an increase in the volumetric efficiency of the engine [15] by lowering its intake mixture temperature. Ethanol has a high octane number and contains oxygen, therefore, its mixture with gasoline reduces the tendency to "knock" and promotes the reduction of emissions of some exhaust gases [16].

Oztop et al. [17] evaluated the performance and emissions of exhaust gases of an SI engine fuelled with a mixture of gasoline and pyrolysis distillates from tire wastes. The authors concluded that this new fuel could partially replace gasoline blends by up to $60 \%$ without significant changes in engine performance and exhaust emissions.

Suiuay et al. [18] evaluated the performance and emissions of exhaust gases of an SI engine fuelled with a mixture of gasoline and pyrolysis bio-oil distillates from the hard resin of Yang (gasoline-like fuel (GLF)). The authors concluded that the GLF showed better results than gasoline for torque, brake thermal efficiency, and brake specific fuel consumption; GLF had lower emissions of $C O$ and unburned hydrocarbons (UHC) and higher emissions of $\mathrm{NO}_{x}$.

The use of ternary mixtures of gasoline and two different biofuels has been tested by different authors with the purpose of achieving optimal combustion conditions by combining fuels with different chemical composition and fuel properties [19,20].

Kareddula et al. $[19,20]$ published two papers evaluating the performance and emissions of exhaust gases of an SI engine with pyrolysis bio-oils of non-distilled plastic waste (PPO) and distilled PPO (DPPO). The first test was performed with $15 \%$ PPO and showed a reduction in thermal efficiency and a substantial increase in $\mathrm{NO}_{x}$ emissions [19]. Next, they tested gasoline with $15 \%$ PPO and 5\% ethanol and observed that the engine's performance was improved compared to gasoline and gasoline 
with PPO; $\mathrm{CO}$ and $\mathrm{NO}_{\mathrm{x}}$ emissions were significantly reduced while UHC emissions increased [19]. For the second study [20], they evaluated gasoline blends with different DPPO levels. The authors verified that the mixture with 50\% DPPO provided the maximum performance (power and thermal efficiency) when compared to gasoline. Mixtures with lower levels of DPPO produced a decrease in $\mathrm{CO}_{2}$ and $\mathrm{UHC}$ emissions and an increase in $\mathrm{CO}$ and $\mathrm{NO}_{x}[20]$.

The incorporation of a third component with different characteristics may achieve the attenuation of unwanted characteristics of a given fuel blend. That was the case for the addition of ethanol to the mixture of gasoline + bio-oil from plastic pyrolysis (PPO) that improved the engine's performance, with $\mathrm{NO}_{\mathrm{x}}$ emissions being marginally controlled. Gasoline and PPO are perfectly miscible, but the higher density and viscosity of PPO may negatively impact engine performance of the fuel blend, thus, ethanol addition may attenuate these properties and increase oxygen local availability, improving mass transfer and combustion efficiency [19].

Bio-oil or bio-oil distillates derived from materials originating from oil (plastics and tires) were used for these three studies $[17,19,20]$.

There are very few studies that evaluate the use of distillates from bio-oils mixed with gasoline in engines. Reported tests with ternary mixtures of gasoline with bio-oil distillates and ethanol in small percentages are even rarer. We did not identify any work whose analysis relied on the use of light distillates of lipid bio-oils in engines.

The aim of this study was to evaluate the feasibility of adding small quantities of pyrogasoline (a lipid-derived biofuel produced by pyrolysis and distillation), as an additive for gasoline. To achieve this goal, different binary and ternary mixtures of gasoline, pyrogasoline, and ethanol were used as fuels in an SI engine, and the impact of fuel composition in engine performance (torque, energy consumption, and efficiency) and pollutant emissions of exhaust gases $\left(\mathrm{CO}, \mathrm{UHC}, \mathrm{NO}_{\mathrm{x}}\right)$ was evaluated.

\section{Experimental Procedures}

\subsection{Pyrolysis Bio-Oil Distillation}

Liquid pyrolysis products, obtained from various lipid raw materials unfit for the production of biodiesel (used cooking oil, high acid poultry oil, palm oil, high acidity olive oil, and olive husk oil) and under different operating conditions (temperature, pressure, residence time, and different atmospheres), were combined and distilled together to obtain a volume of distillate suitable for engine combustion tests.

The pyrolysis liquids were first decanted to isolate the aqueous fraction from the organic, followed by distillation to separate volatile and non-volatile bio-oil components (Figure 1). Distillation led to two liquid fractions: a more volatile fraction (F1) collected between room temperature and $195^{\circ} \mathrm{C}$ and a less volatile one (F2) recovered between $195^{\circ} \mathrm{C}$ and the final distillation temperature (around $250{ }^{\circ} \mathrm{C}$ ).

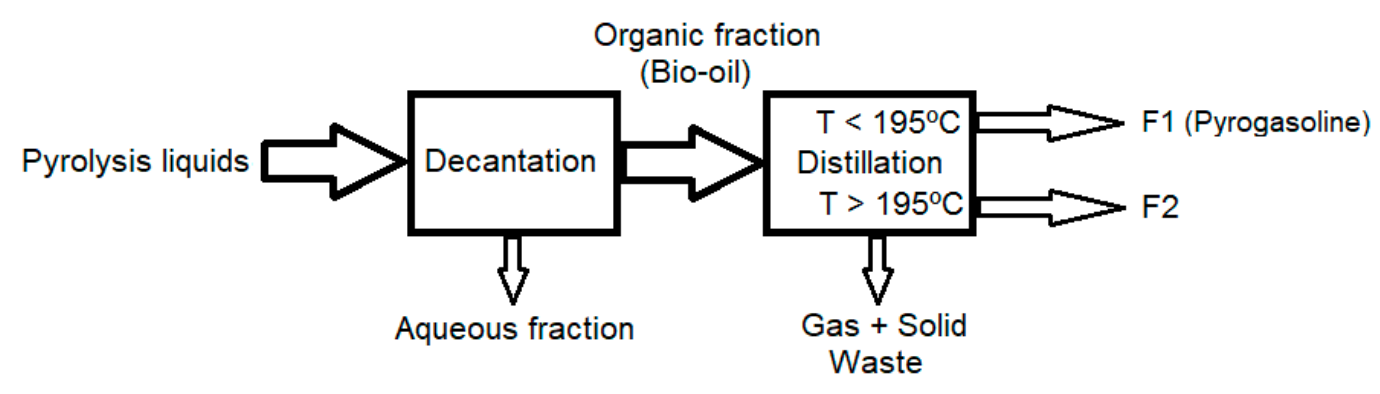

Figure 1. Distillation yields.

The crude bio-oil and light fraction of distillation (F1, pyrogasoline) presented high higher heating values (HHVs), respectively 41.3 and $42.2 \mathrm{MJ} \mathrm{kg}^{-1}$, which gives them excellent fuel properties. Only fraction F1 (pyrogasoline) was used in this work. 


\subsection{Fuels for the Tests}

The engine tests were performed with six fuels: five were mixtures obtained from gasoline with pyrogasoline and/or ethanol; the sixth was gasoline used as a reference fuel. Fuels are identified in Table 1.

Table 1. Identification of the fuels used in the engine tests (\%wt.).

\begin{tabular}{cccc}
\hline Fuel Code & Gasoline (G) & Pyrogasoline (PG) & Ethanol (E) \\
\hline G100 & 100 & & \\
G97 + PG3 & 97 & 3 & 1.5 \\
G97 + PG1.5 + E1.5 & 97 & 1.5 & \\
G95 + PG5 & 95 & 5 & 5 \\
G95 + E5 & 95 & 2.5 & 2.5 \\
G95 + PG2.5 + E2.5 & 95 & 2.5 \\
\hline
\end{tabular}

Gasoline (RON 95) and ethanol (96\% v/v) were purchased on the market.

The density, elemental composition, higher heating value (HHV), and functional groups were measured for each fuel. The density was determined gravimetrically. The elemental composition (C, H, N, and S) was determined using a Flash EA 112 CHNS analyser (Thermo Fisher Scientific, Waltham, MA USA), and the oxygen concentration was obtained by the difference. To determine the HHV, a model C200 calorimeter (IKA, Staufen, Germany) was used and the liquids were weighted and analysed using model C9 gel capsules from the same manufacturer. HHV values were obtained indirectly using Equation (1):

$$
m_{\text {total }} * H H V_{\text {total }}=m_{\text {gel }} * H H V_{\text {gel }}+m_{f u e l} * H H V_{f u e l}
$$

The lower heating value (LHV) was estimated using Equation (2) (ASTM D249, 2002):

$$
L H V\left(M J \cdot \mathrm{kg}^{-1}\right)=H H V-0.2122 \times H(\%)
$$

To identify the functional groups, a Fourier Transform Infrared (FT-IR) spectrophotometer from Nicolet iS10, (Thermo Scientific, Waltham, MA USA) was used; to collect the spectra and identify the main bands, the TS OMNIC program was used.

\subsection{Experimental Setup}

The tests were carried out on a 1.6 L, L4, 4-stroke gasoline engine (Figure 2) that maintained most of the original characteristics, except the intake manifold and valve seats (which were slightly increased in diameter). It was optionally tested without a catalytic converter. The technical specifications of the engine are summarized in Table 2.

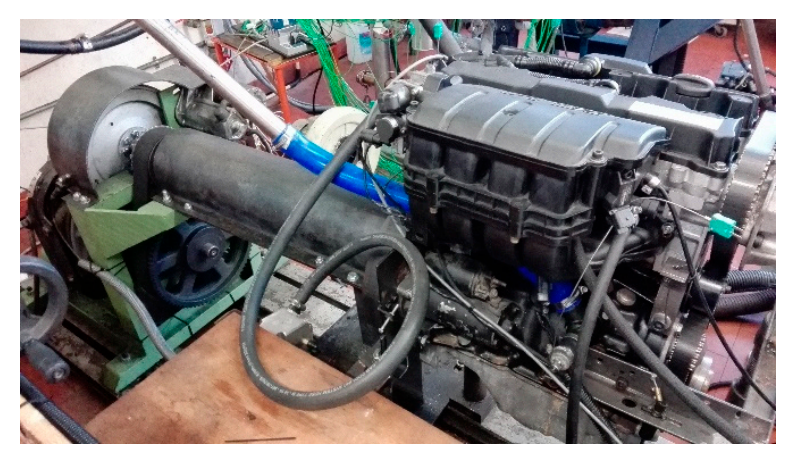

Figure 2. TU5 JP4 engine and Telma CC-125 dynamometer. 
Table 2. Technical specifications of the $1.6 \mathrm{~L}, 16 \mathrm{v}$ gasoline engine [21].

\begin{tabular}{cc}
\hline Engine designation & PSA TU5 JP4 \\
Engine capacity $\left(\mathrm{cm}^{3}\right)$ & 1587 \\
Bore $x$ Stroke $(\mathrm{mm})$ & $78.5 \times 82.0$ \\
Number of valves & 16 \\
Compression ratio & $10.8: 1$ \\
Injection system & Multipoint \\
Maximum power $(\mathrm{kW})$ & 87 at $6600 \mathrm{rpm}$ \\
Maximum torque $(\mathrm{N} . \mathrm{m})$ & 145 at $5200 \mathrm{rpm}$ \\
\hline
\end{tabular}

The test bench had an eddy current dynamometer (Telma CC-125) with electronic speed control to which this engine was attached (Figure 2). The engine was controlled by a $100 \%$ programmable electronic control unit from the ECU MASTER that enabled the injection and ignition to be mapped. A scale with resolution of $0.1 \mathrm{~g}$ (KERN FKB) was used to measure the fuel mass flow.

With the aid of an oxygen sensor (lambda probe- $-\lambda$ ) adjustments were performed to the injection map until a stoichiometric air/fuel ratio $(\lambda=1)$ was reached for each fuel at all points on the map. Adjustments were also made to the ignition map (Figure 3), with the ignition being advanced until reaching the maximum effective torque point MBT (maximum braque torque) without knock.

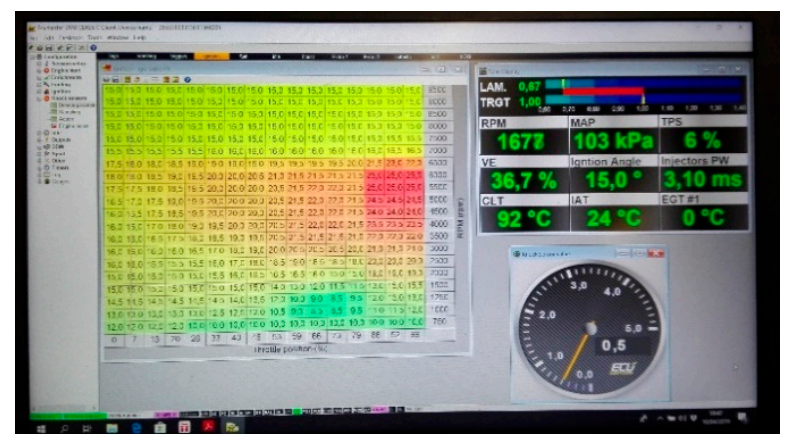

Figure 3. Ignition map.

The six fuels were tested at different speeds between 2000 and $6000 \mathrm{rpm}$ in increments of $500 \mathrm{rpm}$. Most of the tests were performed at full load (100\% throttle or wide-open throttle (WOT)), although some engine tests were carried out at partial loads $(\sim 50 \%)$ due to the amount of available pyrogasoline. Engine performance data and pollutants in the exhaust gases were recorded. The registrations occurred after stabilizing the engine ( $20 \mathrm{~s})$, and each registration lasted for $30 \mathrm{~s}$.

To characterize the exhaust gas emissions, a gas analyser model AVL DIGAS 4000 Light was used. This equipment has five electrochemical sensors for measuring the compounds $\mathrm{CO}, \mathrm{CO}_{2}, \mathrm{O}_{2}, \mathrm{UHC}$, and $\mathrm{NO}_{x}$, and the value of $\lambda$ is calculated. The condensates were drained upstream of the analyser.

The engine performance analysis makes use of some measured or related parameters. The equations are shown in Supplementary Materials.

\section{Results and Discussion}

The first tests were performed with gasoline with $5 \%$ bio-oil (without distillation). These tests did not go well; they gave rise to a liquid purge through the head gasket and an intense odour in the laboratory. Additionally, there was a significant decrease in engine torque. Immediate discontinuation of the test prevented major engine problems. The disassembly and cleaning of the engine made it possible to identify the problem: The engine was not able to burn the heavier compounds of the bio-oil. This preliminary test definitively eliminated the use of non-distilled bio-oils in SI engines. All subsequent tests were only carried out with the light distilled part of the pyrolysis bio-oil (pyrogasoline). Kumar et al. [19] made the same conclusions, although for different reasons. 


\subsection{Fuel Characteristics}

Table 3 and Figure 4 show the measured properties and the elementary compositions of the base fuels used.

Table 3. Density $(\rho)$, higher heating value (HHV), lower heating value (LHV), $\mathrm{pH}$, and stoichiometric air-fuel ratio (AFR) of the fuels used in the formulation of the mixtures.

\begin{tabular}{|c|c|c|c|c|c|}
\hline Fuel & $\rho\left(\right.$ g.cm $\left.{ }^{-3}\right)$ & HHV (MJ.kg ${ }^{-1}$ ) & LHV (MJ.kg ${ }^{-1}$ ) & $\mathrm{pH}$ & AFR \\
\hline Gasoline & 0.75 & 42.6 & 40.0 & - & 14.2 \\
\hline Pyrogasoline & 0.85 & 42.2 & 39.4 & 4.5 & 13.0 \\
\hline Ethanol & 0.80 & 27.5 & 24.6 & - & 8.3 \\
\hline
\end{tabular}

$\begin{array}{lll}\square \text { Gasoline } \quad \text { Pyrogasoline } & \bullet \text { Ethanol } & \times \text { G97+PG3 } \\ \times \text { G97+PG1.5+E1.5 } \times \text { G95+PG5 } & \times \text { G95+E5 } & \times \text { G95+PG2.5+E2 } .5\end{array}$

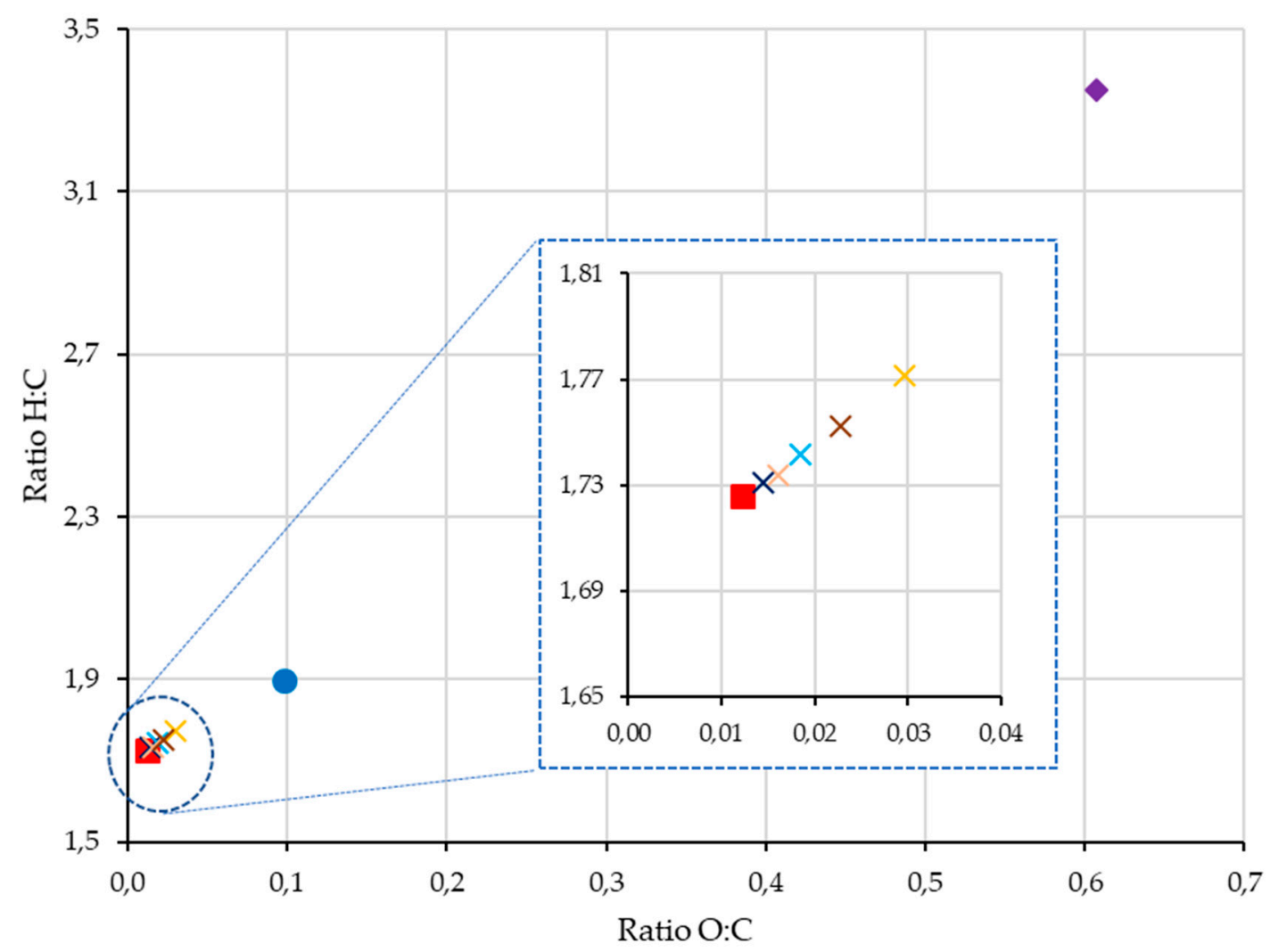

Figure 4. Elementary composition of the base fuels (gasoline, G; pyrogasoline, PG; and ethanol, E) and of the fuel mixtures.

Ethanol has a low energy content, less than two thirds of gasoline and pyrogasoline.

Binary and ternary mixtures of gasoline with pyrogasoline and ethanol in small percentages have practically the same $\mathrm{O}: \mathrm{C}$ and $\mathrm{H}: \mathrm{C}$ ratios as gasoline (Figure 4).

The functional groups of gasoline and pyrogasoline were identified by FT-IR. Table 4 shows the wave numbers of the main bands and functional groups assigned. 
Table 4. Wave numbers $\left(\mathrm{cm}^{-1}\right)$ of the main bands of gasoline and pyrogasoline and the assigned functional groups $[22,23]$.

\begin{tabular}{ccl}
\hline Gasoline & Pyrogasoline & \multicolumn{1}{c}{ Functional Group/Assignment } \\
\hline 3015 & - & Alkene C-H strech \\
2957 & 2955 & Methyl C-H asym./sym. stretch \\
2923 & 2922 & Methylene C-H asym./sym. stretch \\
2870 & - & Methyl C-H asym./sym. stretch \\
- & 2853 & Methylene C-H asym./sym. stretch \\
- & 1710 & Carboxylic acid C=O strech \\
1608,1506 e 1490 & - & Aromatic ring stretch \\
1456 & 1457 & Methylene/Methyl C-H asym./sym. bend \\
1377 & 1377 & Methyl C-H asym./sym. bend \\
- & 1285 & Aromatic ester C-O strech \\
1022 & - & Aromatic C-H in-plane bend \\
- & 909 & Alkene C=C blend \\
$878-698$ & 722,698 & Aromatic C-H out-of-plane bend \\
\hline
\end{tabular}

Gasoline consists of light alkanes, few cycloalkanes, and many aromatic compounds. Pyrogasoline consists of alkanes, cycloalkanes, carboxylic acids, alkenes, and a few aromatics.

Pyrogasoline has less aromatics and branched alkanes than does gasoline; this difference in composition, according to Shamsul et al. [24], suggests that pyrogasoline has a lower octane number than gasoline.

Figure 5 presents the calculation of LHV and the air-fuel (AFR) for the fuels used in the tests.

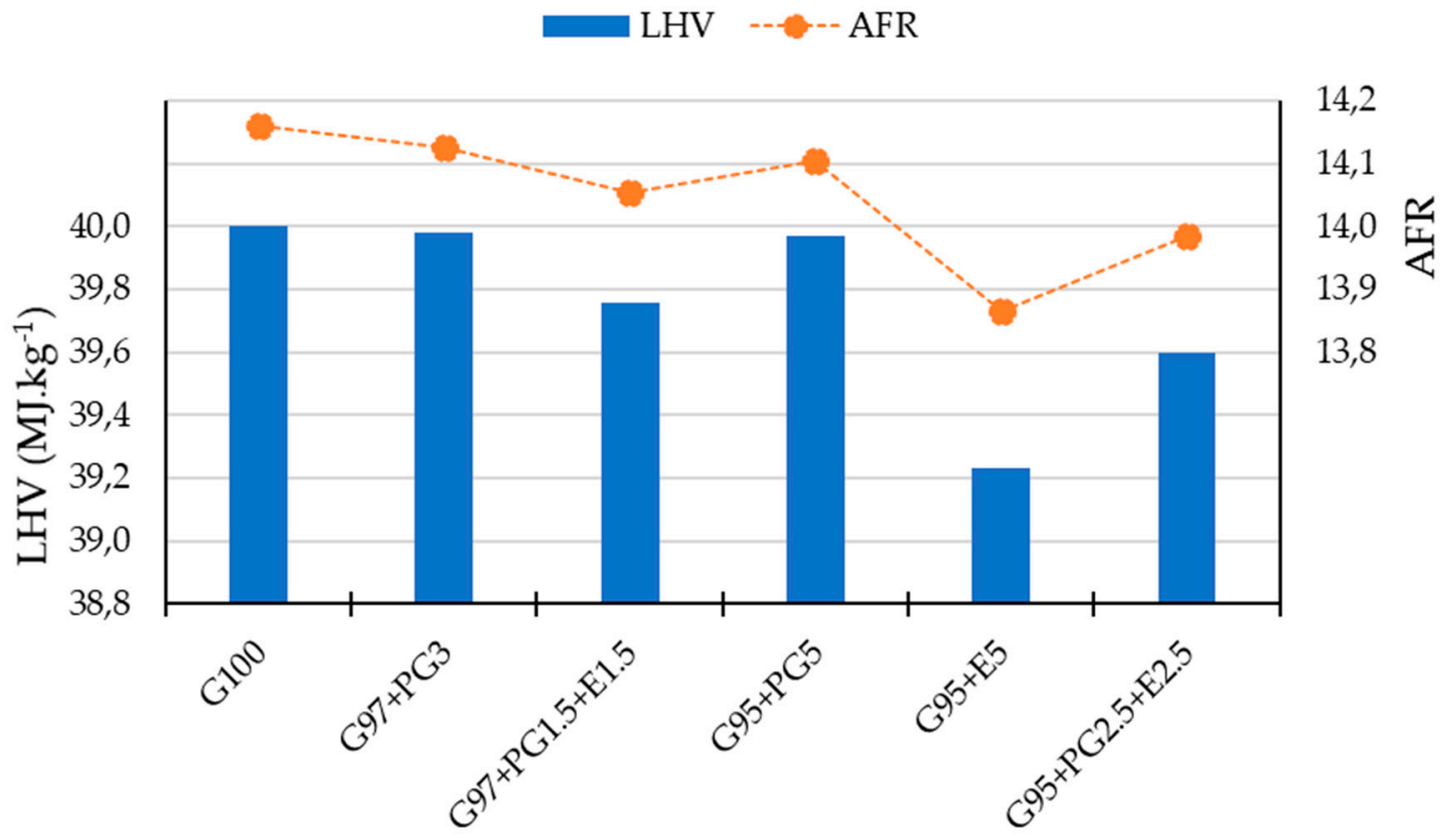

Figure 5. Lower heating value (LHV) and air-fuel ratio (AFR) for the fuels and fuel mixtures used in the engine tests.

\subsection{Performance Analysis}

The engine tests were performed on two consecutive days without major temperature or atmospheric pressure changes.

Figure 6 shows the torque and ignition advance curves of the six fuels used in the engine tests as a function of engine speed. 


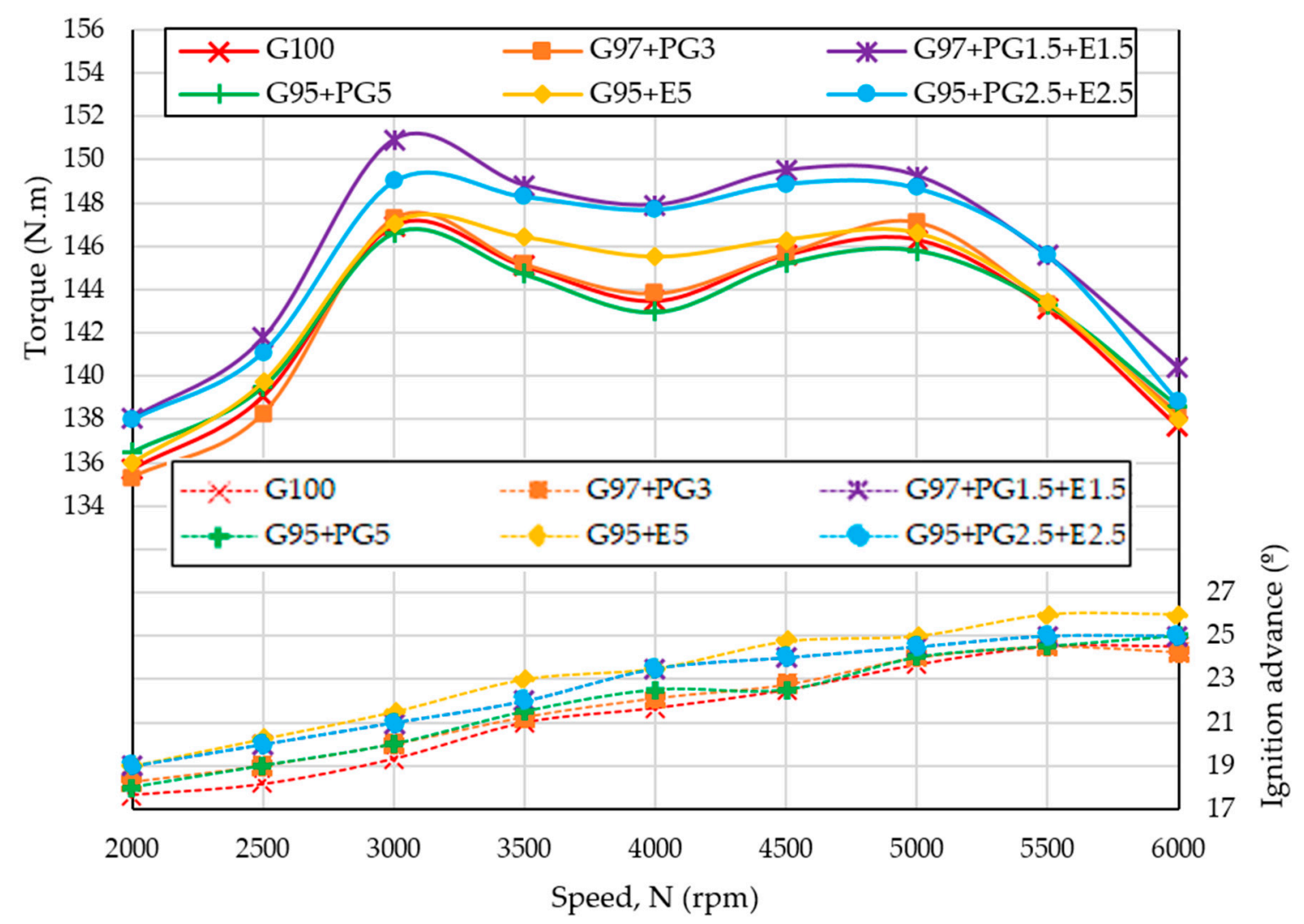

Figure 6. Torque (solid) and spark advance (dashed) curves for the different fuels.

The existence of different ignition advance curves shows that the different fuels properties influence the engine performance. The binary and ternary mixtures with ethanol have higher ignition advances than the rest of the fuels.

It appears that all torque curves showed two peaks, one close to $3000 \mathrm{rpm}$ and the other close to $5000 \mathrm{rpm}$, as is normal in SI engines.

It was also verified that the six analysed fuels reached a maximum torque higher than that announced by the manufacturer. Gasoline reached a maximum torque of 146.3 N.m at 5000 rpm (instead of the 145 N.m at $5200 \mathrm{rpm}$ announced), probably due to the referred small improvements introduced in the engine and/or due to the nonexistence of the catalytic converter.

One torque curve that is frankly the best: G97 + PG1.5 + E1.5. The other ternary mixture (G95 + PG2.5 + E2.5) is the second best, showing that the ternary mixtures positively improve the engine's performance. In the middle position is the binary mixture with ethanol G95 + E5. In the lower positions are the pump gasoline G100, the G97 + PG3, and the G95 + PG5, which are practically coincident. Binary mixtures with pyrogasoline alone did not seem to improve nor worsen the engine's performance compared to gasoline. The relative positioning of the G95 + E5 and G100 curves is in accordance with the literature [25]. Although the addition of ethanol slightly improved the base gasoline torque, it did not improve it as much as did the addition of pyrogasoline + ethanol.

Fuel G97 + PG1.5 + E1.5 had a slightly higher torque than that of G95 + PG2.5 + E2.5. The explanation may be found in the concentration of heavy pyrogasoline compounds that are solvated by the volatile components of gasoline.

Note that the blends containing ethanol are those with the best torque, which can be explained by the higher octane number of ethanol. They also allow the higher ignition advance without knock, which also confirms higher octane numbers.

Using the gasoline results as a comparison, Figure 7 shows the torque variations of the various fuels. 


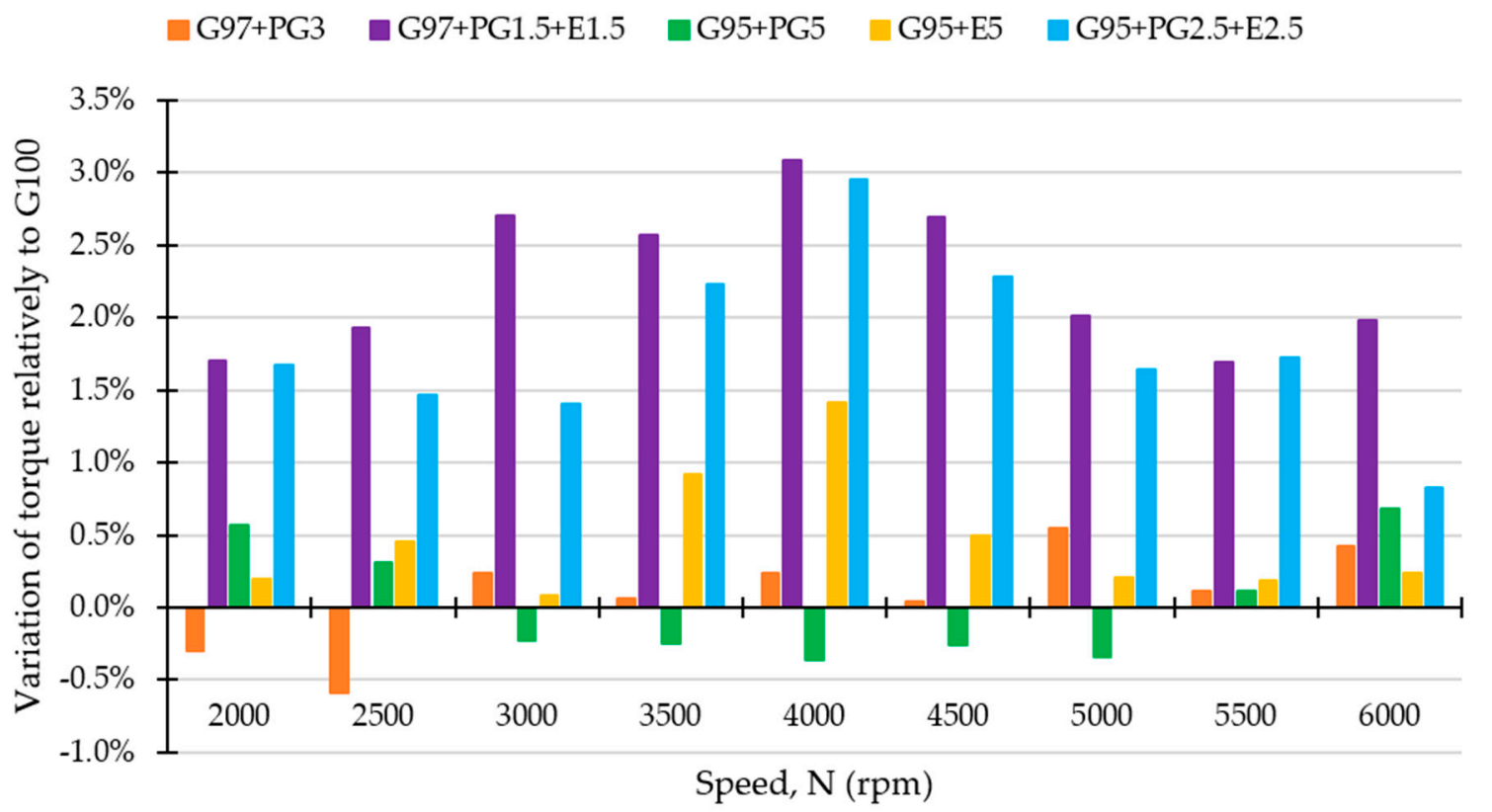

Figure 7. Torque variations ( $\%$ ) of the various fuel mixtures containing $97 \%$ and $95 \%$ gasoline in relation to the torque of $100 \%$ gasoline.

The results prove that the addition of small percentages of pyrogasoline and/or ethanol to commercial RON95 gasoline is beneficial for torque and power.

The ternary mixtures G97 + PG1.5 + E1.5 and G95 + PG2.5 + E2.5 present torque gains, between 0.8 and $3.1 \%$, in relation to gasoline.

At low and high engine speeds, the torque difference between fuels is reduced.

After analysing the binary mixtures, we can conclude that:

(a) the engine worked well with all tested fuels;

(b) the incorporation of pyrogasoline did not negatively alter the engine torque;

(c) there is a synergistic gain in the presence of pyrogasoline and ethanol in small percentages in blends with gasoline.

Figure 8 shows the energy consumption for the different fuels along the engine speed range. As expected, the addition of ethanol reduced the energy content of the mixture, due to ethanol's lower LHV. The addition of pyrogasoline had the opposite effect, with the mixtures using it increasing their energy, as the lower stoichiometric air/fuel ratio of the pyrogasoline (Table 3) in relation to gasoline more than compensated for its lower LHV.

Figure 9 shows the brake specific energy consumption (BSEC) curves of the various fuels.

Through these specific consumption curves, two consumption minimums were identified at 3100 and $5000 \mathrm{rpm}$.

The binary mixture with $3 \%$ pyrogasoline had a consumption profile identical to that of $100 \%$ gasoline at most engine speeds, but when pyrogasoline incorporation was increased to $5 \%$, an increase of BSEC occurred, especially in the range from 3000 to $5500 \mathrm{rpm}$, indicating that this biofuel was not being optimally burned. The binary mixture of $95 \%$ gasoline and $5 \%$ ethanol had the lowest brake specific energy consumption over the entire range of engine speeds, but the ternary mixture of $95 \%$ gasoline with $2.5 \%$ ethanol and $2.5 \%$ pyrogasoline also showed a consumption profile significantly lower than that of $100 \%$ gasoline.

Figure 10 shows the effective efficiency curves $\left(\eta_{e}\right)$ of the various fuels.

The efficiency of the engine, using the different fuels, lies between 36 and $39 \%$ and, obviously, has opposite trends to the BSEC curves. 
The efficiency curves closely follow the torque curves. As expected, the best average efficiency was achieved by G95 + E5 and the worst by G95 + PG5.

Using the results of gasoline as a baseline, Figure 11 shows the differences in the effective efficiency $\left(\eta_{e}\right)$ of the various mixtures in relation to gasoline.

An analysis of Figure 11 shows that the efficiency differences are small, but the fuel blends with $2.5 \%$ and $5 \%$ ethanol showed improvements of $0.4 \%$ to $1.2 \%$, respectively, of engine efficiency over the speed range. Although revealing the highest engine efficiency, the mixtures containing ethanol did not display the highest torque (Figure 6). The reason is the lower energy content of the mixture, as shown in Figure 8.

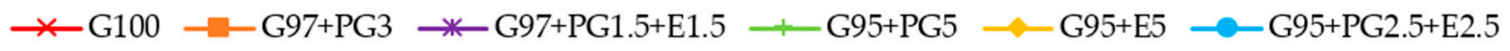

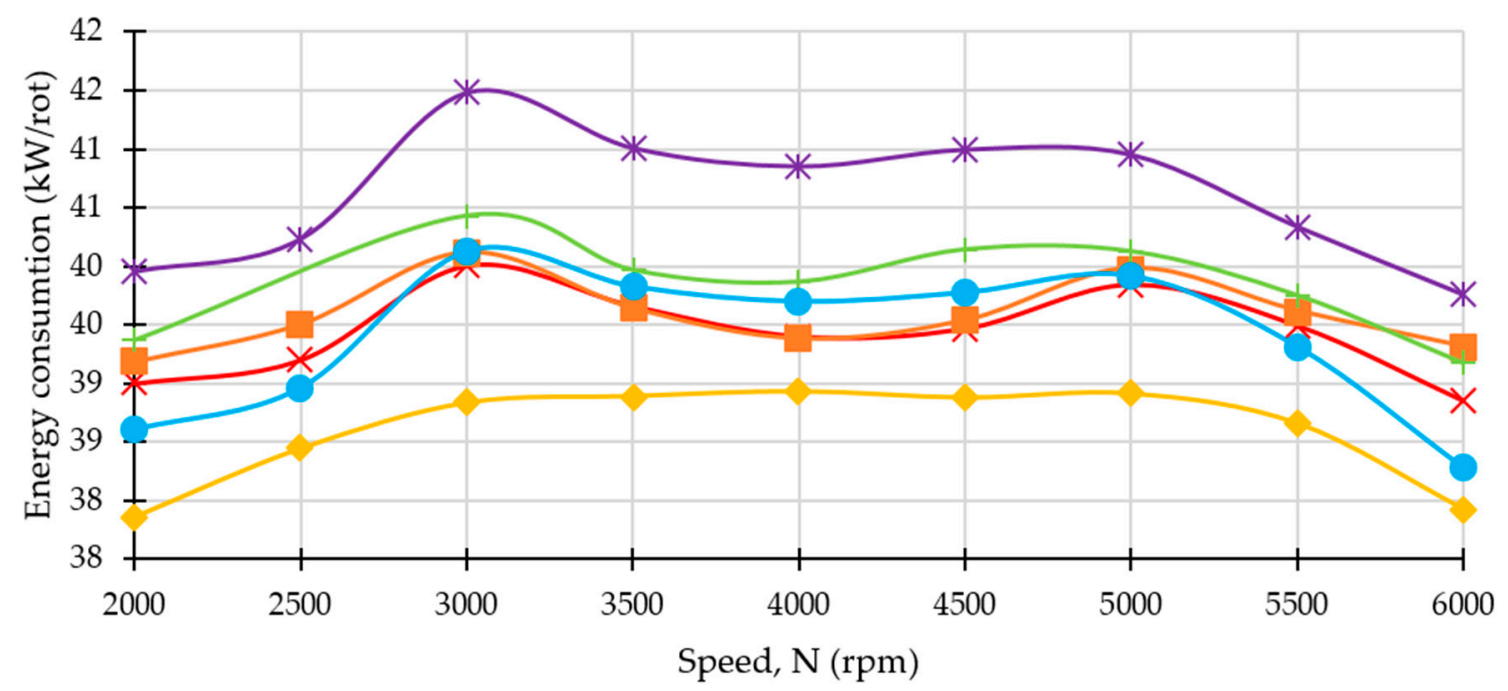

Figure 8. Energy consumption for the different fuels.

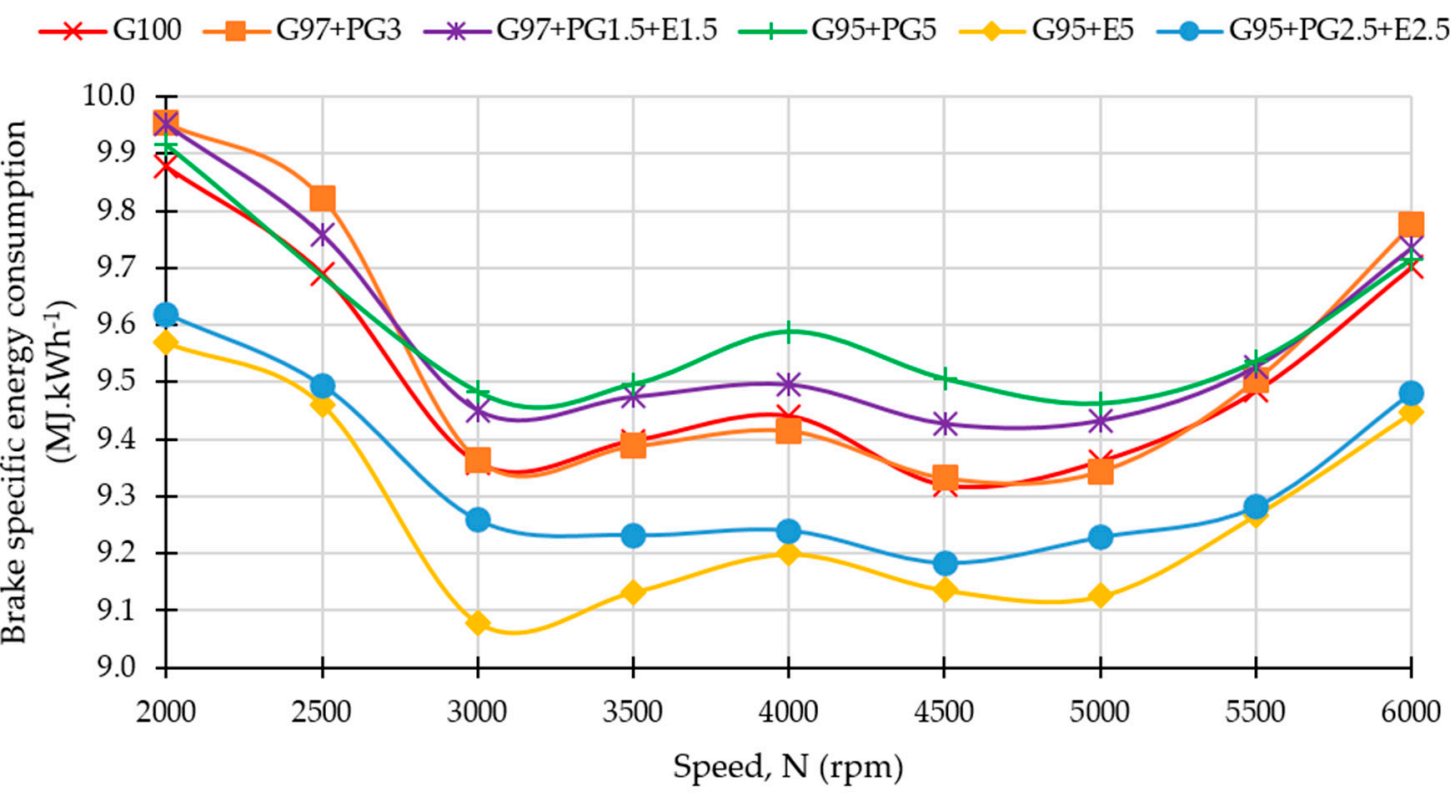

Figure 9. Brake specific energy consumption (BSEC) for the different fuels. 
$*$ G100 - $-\mathrm{G} 97+\mathrm{PG} 3 \rightarrow$ G97+PG1.5+E1.5 —G95+PG5 $\longrightarrow \mathrm{G} 95+\mathrm{E} 5 \multimap \mathrm{G} 95+\mathrm{PG} 2.5+\mathrm{E} 2.5$

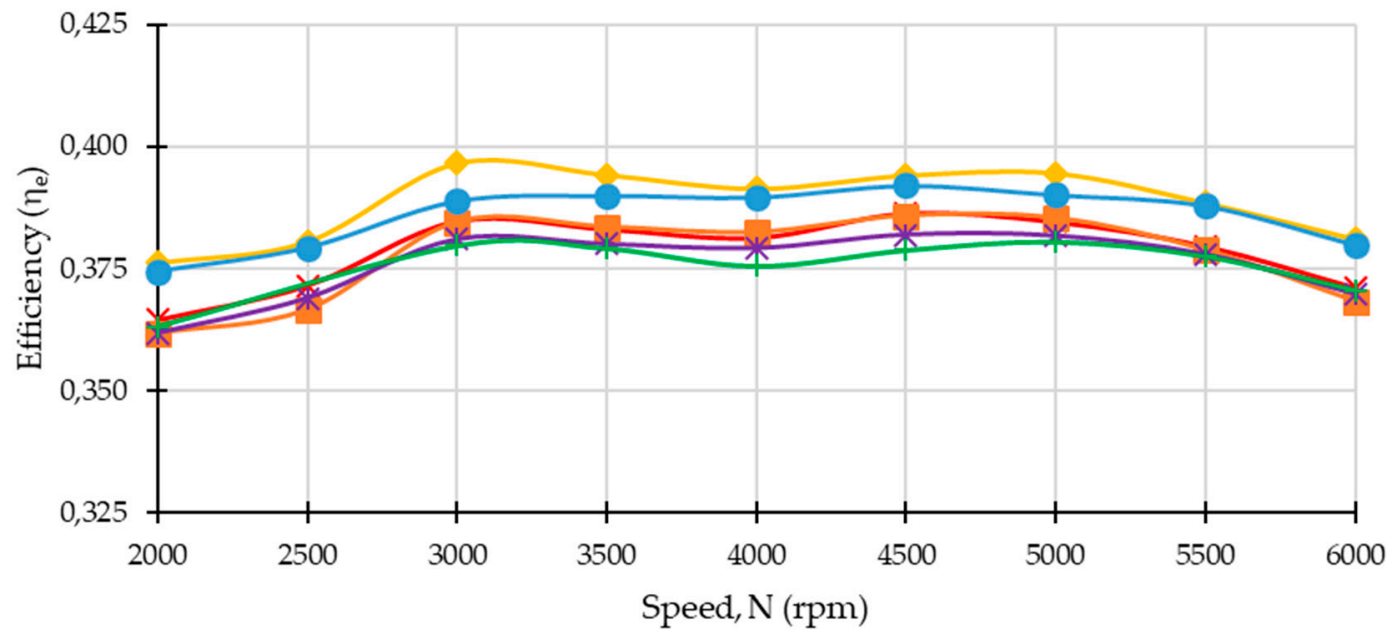

Figure 10. Effective efficiency curves of the fuels used in the tests.

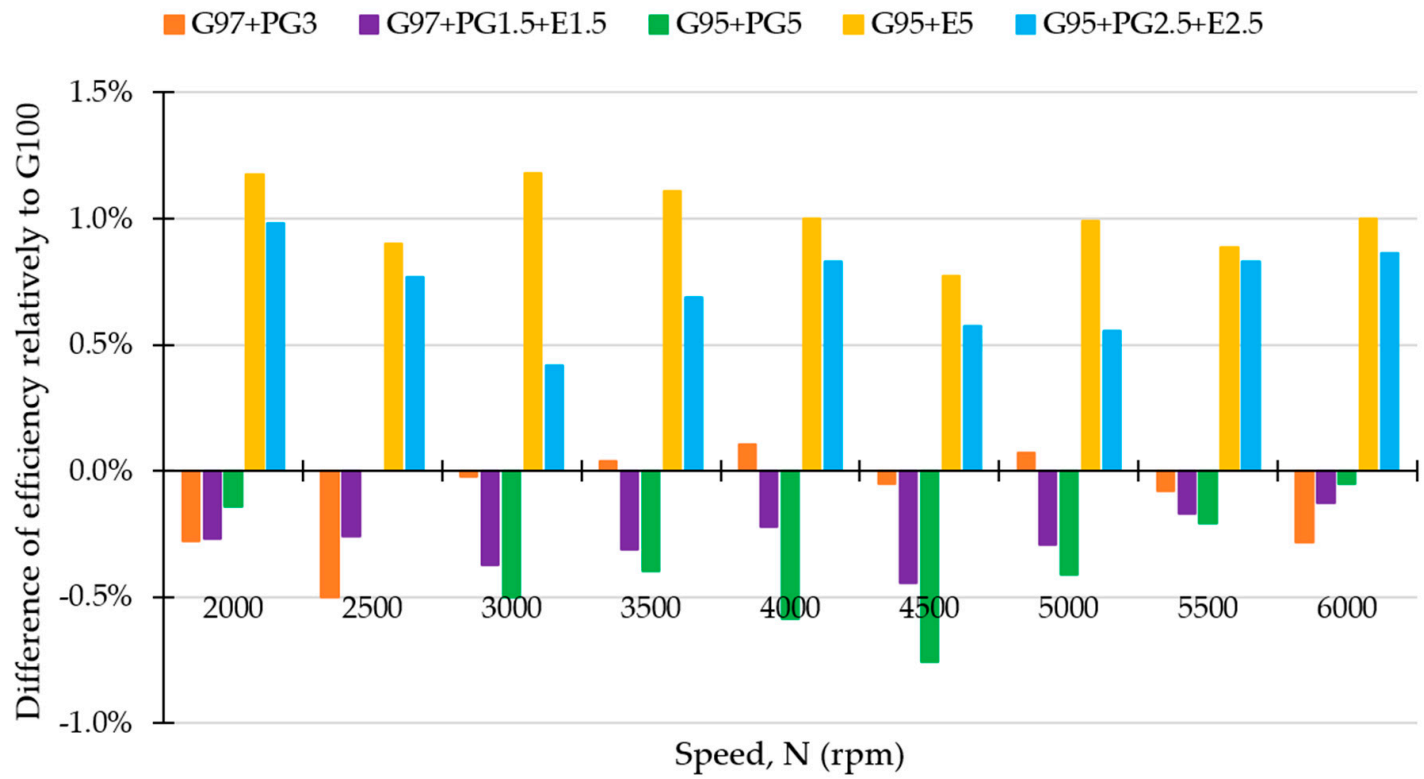

Figure 11. Differences in the efficiency of fuel mixtures in relation to gasoline.

\subsection{Emission Analysis}

Although values for all rotation speeds were recorded, all points where the condition $\lambda=1.00$ was not observed were removed from the graph. Figure 12 shows the $\mathrm{CO}$ emissions from the fuels used in the tests.

$\mathrm{CO}$ emissions follow a $\mathrm{W}$ pattern as can be seen in Figure 12. The $\mathrm{CO}$ graph has two minimums that coincide with the maximum torque, which makes sense; these two points are also the ones with the highest engine efficiency. The engine burns well at these speeds.

The G95 + E5 and G97 + PG1.5 + E1.5 fuels achieved the lowest and highest CO emissions, respectively. This difference in behaviour may be due to the higher viscosity of pyrogasoline, which worsens fuel atomization and leads to incomplete combustion.

Figure 13 shows UHC emissions of the fuels used in the tests. 

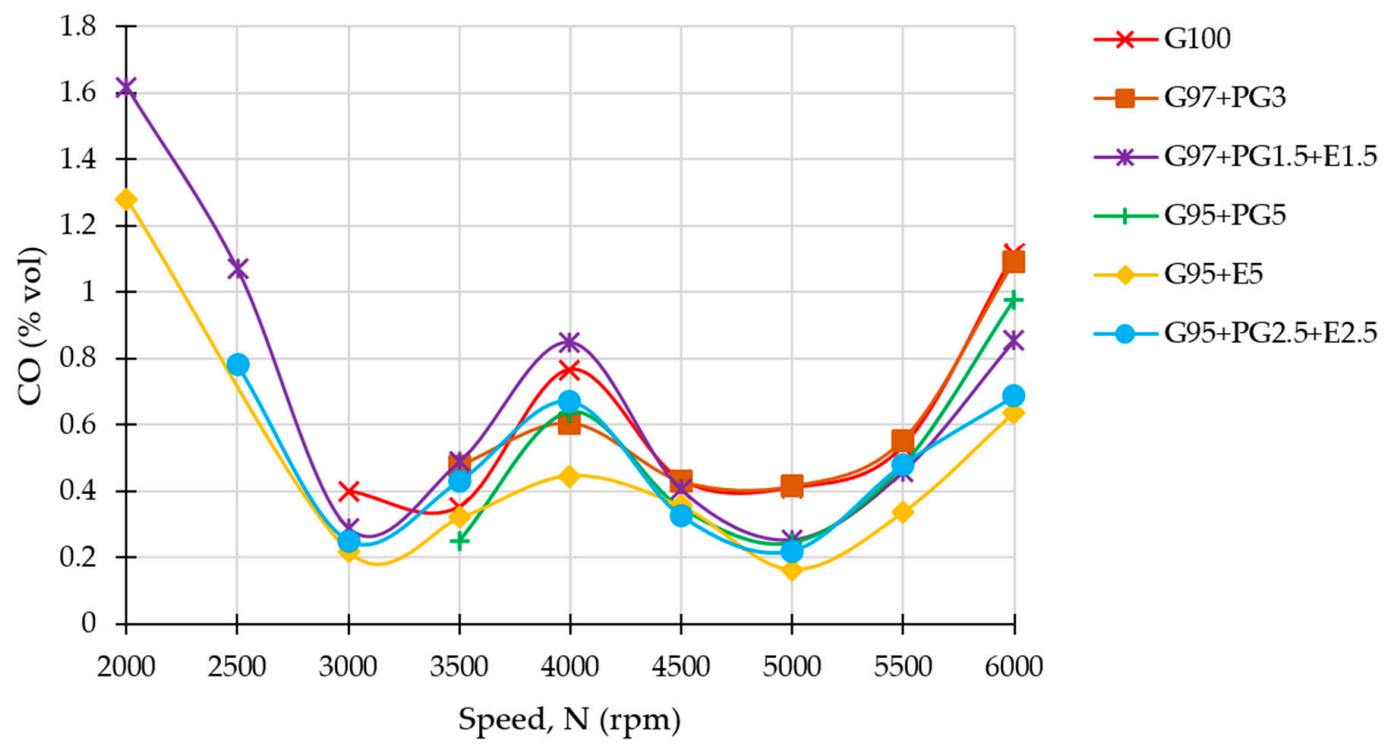

Figure 12. CO emissions of fuels used in the tests.
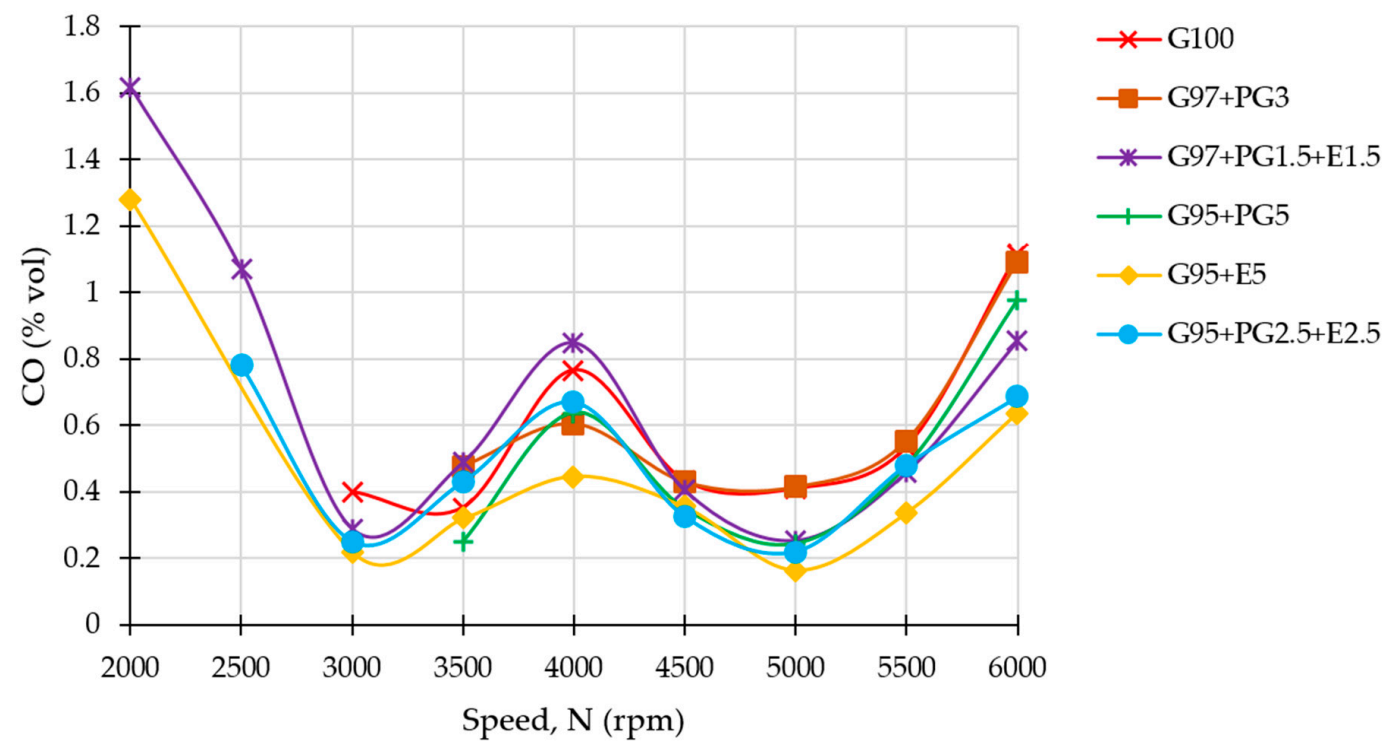

Figure 13. Unburned hydrocarbon (UHC) emissions of the fuels used in the tests.

Again, points that did not meet the criterion $\lambda=1.00$ are not shown in the graph. The various points do not follow specific trends of the curves for torque and for $\mathrm{CO}$ emissions, so trend curves approximated by 2nd degree polynomials were used, which seems to make more sense.

The design of the UHC curves seems to show higher values for low and for high engine speed, while displaying lower values for intermediate speeds. In order to try to reveal more meaningful trends, power was used instead of engine rpm, as it may be more related to emission production, although the results were similar. So, the weak turbulence (lower speeds) and reduced combustion time (higher speeds) seems to be responsible for increasing the UHC emissions in the exhaust gases.

Gasoline displays the lowest UHC curve while binary mixtures with pyrogasoline (G97 + PG3 and G95 + PG5) have the highest UHC curves, so it seems that the addition of pyrogasoline increases the emission of that pollutant.

Figure 14 shows $\mathrm{NO}_{\mathrm{x}}$ emissions from the various fuels used in the tests. The conditions used for Figure 13 were also used in Figure 14. 


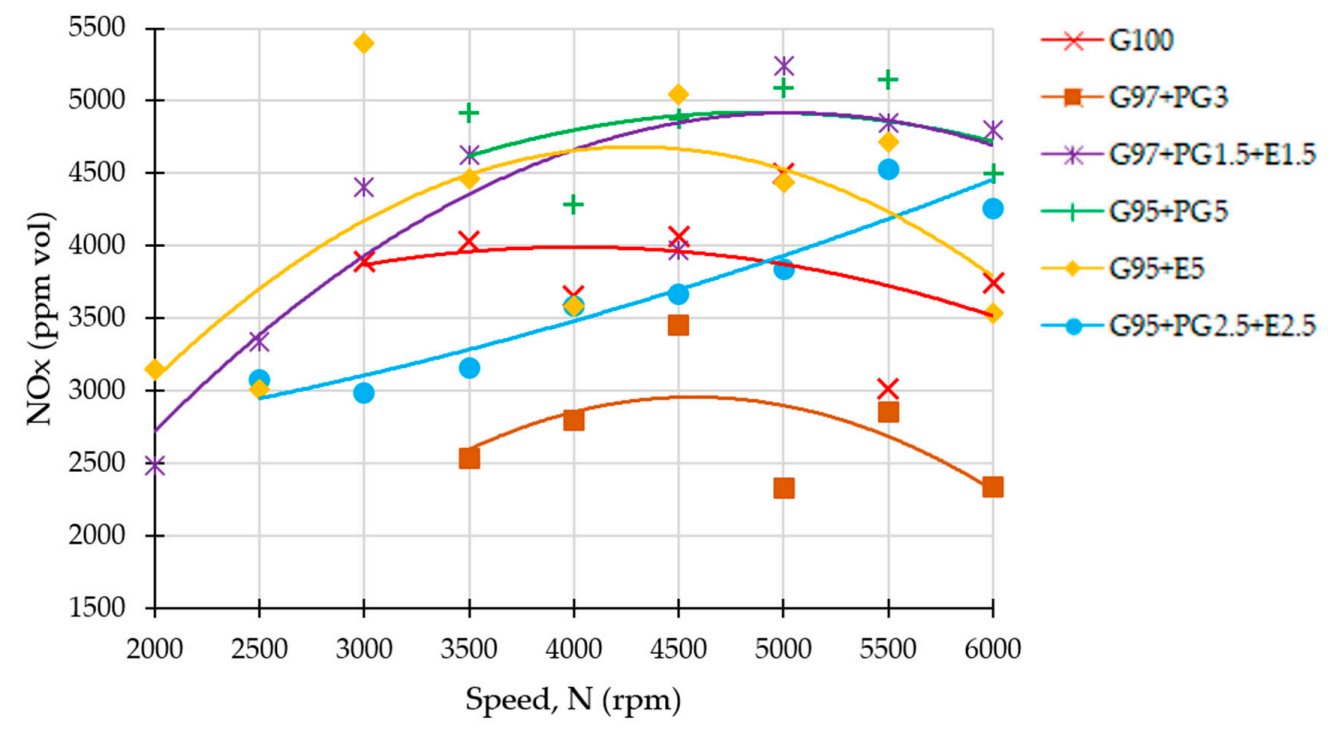

Figure 14. $\mathrm{NO}_{\mathrm{x}}$ emissions for the fuels used in the tests.

In general, $\mathrm{NO}_{\mathrm{x}}$ emissions seem to increase with engine speed, as the power also increases, and $\mathrm{NO}_{\mathrm{x}}$ emissions are related to gas temperature.

The very high $\mathrm{NO}_{\mathrm{x}}$ values are probably related with the changes made to the engine that improved its performance, but additionally increased $\mathrm{NO}_{x}$.

The longer the ignition advance, the higher is the pressure and temperature achieved by the combustion products that increase $\mathrm{NO}_{x}$ production [25]. In general, the ignition advance is limited by the production of $\mathrm{NO}_{x}$, but this trend was not seen here. The advance of the ignition was only limited by the knock onset and the torque maximization. Therefore, minimal changes of the ignition advance may show larger excursions of $\mathrm{NO}_{\mathrm{x}}$ emissions, which may explain the lack of specific trends for this pollutant.

It was supposed that oxygenates present $\mathrm{NO}_{x}$ emissions exceeding those of the non-oxygenates [14], but this trend has not been fully verified, as $\mathrm{NO}_{\mathrm{x}}$ emissions above and below those of gasoline have been verified with the addition of ethanol. Again, small changes of the ignition advance may result in larger changes than those predicted by the use of oxygenates.

It was not possible to notice a specific behaviour of fuels with pyrogasoline added in relation to $\mathrm{NO}_{\mathrm{x}}$ : G95 + PG5 showed an increase in relation to RON95 gasoline (being practically the mixture that presented the highest $\mathrm{NO}_{\mathrm{x}}$ ), but G97 + PG3 was the mixture that produced lower levels of $\mathrm{NO}_{\mathrm{x}}$. Overall, we can state that the $\mathrm{NO}_{\mathrm{x}}$ emissions do not show an obvious trend in terms of pyrogasoline use as an additive to gasoline.

\section{Conclusions}

Although straight pyrolysis bio-oil should not be used in spark ignition engines (due to the presence of soluble solids and high molecular weight liquids), the light distillates (pyrogasoline) of this bio-oil did prove adequate for use in SI engines.

The characterization of the light fraction of distillate pyrolysis bio-oil points to a similar composition to that of gasoline and comparable LHVs.

Binary mixtures with pyrogasoline or ethanol did not improve or worsen the engine's performance, but ternary mixtures with small percentages of pyrogasoline and ethanol positively improved the engine's performance, with torque gains between 0.8 and $3.1 \%$ compared to commercial gasoline RON95.

Ethanol mixtures showed the highest efficiency values, whereas mixtures with pyrogasoline had the lower values. The best thermal efficiency was achieved by the binary mixture of $95 \%$ gasoline and $5 \%$ ethanol and the worst by the binary mixture of $95 \%$ gasoline and $5 \%$ pyrogasoline. 
Mixtures with oxygenated fuels showed reductions in $\mathrm{CO}$ values. $\mathrm{NO}_{\mathrm{x}}$ emissions from oxygenated fuels had contradictory behaviours in relation to gasoline. The authors could not verify a trend (of increase or decrease) in the pyrogasoline addition to gasoline in terms of $\mathrm{NO}_{\mathrm{x}}$ production.

The results achieved by pyrogasoline seem to accompany those of other additives and biofuels currently used in engines. The tests showed that the use of pyrogasoline is viable as an alternative or as a complement to ethanol, contributing to the increase of the renewable fraction of the fuels in spark ignition engines.

The legislative limitations to supplementing gasoline with first generation ethanol may favour the use of combined additives (ternary mixtures) as used in this work. Furthermore, the use of ternary mixtures of gasoline with oxygenated and non-oxygenated biofuels may allow the achievement of a compromise between engine performance and combustion emissions while contributing to a diversification of the biofuel component. The results obtained in this work also validate an alternative use for low quality lipids as feedstocks to the production of advanced biofuels.

Supplementary Materials: The following are available online at http://www.mdpi.com/1996-1073/13/18/4671/s1.

Author Contributions: Conceptualization, M.G.; Data curation, L.D., F.P.B., and J.M.; Formal analysis, L.D. and J.M.; Investigation, L.D., J.C., and T.A.; Methodology, J.C., T.A., and J.M.; Project administration, M.G.; Resources, M.G.; Supervision, F.P.B. and M.G. All authors have read and agreed to the published version of the manuscript.

Funding: This work was partially funded by Fundação para a Ciência e Tecnologia: UIDB/04077/2020.

Conflicts of Interest: The authors declare no conflict of interest.

\section{Glossary}

$\begin{array}{ll}\rho & \text { Density } \\ \text { AFR } & \text { Air-fuel ratio } \\ \text { BSEC } & \text { Brake specific energy consumption } \\ \text { CO } & \text { Carbon monoxide } \\ \mathrm{CO}_{2} & \text { Carbon dioxide } \\ \text { CNG/LPG } & \text { Compressed natural gas/Liquid petroleum gases } \\ \text { DPPO } & \text { Distilled PPO } \\ \text { E } & \text { Ethanol } \\ \text { GHG } & \text { Greenhouse gas } \\ \text { G } & \text { Gasoline } \\ \text { GLF } & \text { Gasoline-like fuel } \\ \text { HC } & \text { Hydrocarbons } \\ \text { HHV } & \text { Higher heating value } \\ \text { H:C } & \text { Hydrogen-to-carbon ratio } \\ \text { LHV } & \text { Lower heating value } \\ \text { m } & \text { Mass } \\ \text { MBT } & \text { Maximum braque torque } \\ \text { NO } & \text { Oxides of nitrogen } \\ \text { O:C } & \text { Oxygen-to-carbon ratio } \\ \text { ON } & \text { Octane number } \\ \text { PG } & \text { Pyrogasoline } \\ \text { PPO } & \text { Pyrolysis bio-oils of non-distilled plastic waste } \\ \text { SI } & \text { Spark ignition } \\ \text { UHC } & \text { Unburned hydrocarbons } \\ \text { WOT } & \text { Wide open throttle }\end{array}$

\section{References}

1. Cazzola, P. In Proceedings of the Insights Emerging from the 2015 Global EV Outlook (IEA), Goyang, Korea, 4 May 2015. Available online: https://www.iea.org/events/towards-a-global-ev-market (accessed on 4 September 2020).

2. Coelho, P.; Costa, M. Combustão; Edições Orion: London, UK, 2007; p. 714.

3. IEA. Breakdown of Sectoral Final Consumption by Source; IEA: Paris, France, 2011. 
4. Annex, A. Organisation for Economic Co-Operation. Agrcultural Outlook 2008-2017; OECD-FAO: Paris, France, 2008; pp. 1-73.

5. IEA. Technology Roadmap-Biofuels for Transport. 2011. Available online: papers2://publication/uuid/7E683CA3E72A-439B-8C06-CDAADB021565 (accessed on 4 September 2020).

6. EC. Renewable Energy-Recast to 2030 (RED II). Available online: https://ec.europa.eu/jrc/en/jec/renewable-energyrecast-2030-red-ii (accessed on 5 August 2020).

7. Directive 2018/2001/EU. Directive (EU) 2018/2001 of the European Parliament and of the Council on the Promotion of the Use of Energy from Renewable Sources. Off. J. Eur. Union 2018, 2018, 82-209. Available online: https: //eur-lex.europa.eu/legal-content/EN/TXT/PDF/?uri=CELEX:32018L2001\&from=EN (accessed on 4 September 2020).

8. Comission of the European Communities. GREEN PAPER On the Management of Bio-Waste in the European Union; Comission of the European Communities: Brussels, Belgium, 2008; p. 19.

9. European Commission. Directive 2015/1513 of the European parliament and of the council. J. Eur. Union. 2015, 2014, 20-30.

10. Asomaning, J.; Mussone, P.; Bressler, D.C. Thermal deoxygenation and pyrolysis of oleic acid. J. Anal. Appl. Pyrolysis 2014, 105, 1-7. [CrossRef]

11. Billaud, F.; Minh, A.K.T.; Lozano, P.; Pioch, D. Étude paramétrique du craquage catalytique de l'oléate de méthyle. Comptes Rendus Chim. 2004, 7, 91-96. [CrossRef]

12. Demirbas, A. Gasoline-rich Liquid from sunflower oil by catalytic pyrolysis with alumina-treated sodium hydroxide. Energy Sources Part A Recover. Util. Environ. Eff. 2009, 31, 671-678. [CrossRef]

13. Roesyadi, A.; Hariprajitno, D.; Nurjannah, N.; Savitri, S.D. HZSM-5 catalyst for cracking palm oil to gasoline: A comparative study with and without impregnation. Bull. Chem. React. Eng. Catal. 2013, 7, 185-190. [CrossRef]

14. Agarwal, A.K. Biofuels (alcohols and biodiesel) applications as fuels for internal combustion engines. Prog. Energy Combust. Sci. 2007, 33, 233-271. [CrossRef]

15. Zhao, F.; Lai, M.-C.; Harrington, D.L. Automotive spark-ignited direct-injection gasoline engines. Prog. Energy Combust. Sci. 1999, 25, 437-562. [CrossRef]

16. Bušić, A.; Marđetko, N.; Kundas, S.; Morzak, G.; Belskaya, H.; Šantek, M.I.; Komes, D.; Novak, S.; Šantek, B. Bioethanol production from renewable raw materials and its separation and purification: A review. Food Technol. Biotechnol. 2018, 56, 289-311. [CrossRef] [PubMed]

17. Öztop, H.F.; Varol, Y.; Altun, S..; Firat, M. Using gasoline-like fuel obtained from waste automobile tires in a spark-ignited engine. Energy Sources Part A Recover. Util. Environ. Eff. 2014, 36, 1468-1475. [CrossRef]

18. Suiuay, C.; Laloon, K.; Katekaew, S.; Senawong, K.; Noisuwan, P.; Sudajan, S. Effect of gasoline-like fuel obtained from hard-resin of Yang (Dipterocarpus alatus) on single cylinder gasoline engine performance and exhaust emissions. Renew. Energy. 2020, 153, 634-645. [CrossRef]

19. Kareddula, K.; Puli, R. Influence of plastic oil with ethanol gasoline blending on multi cylinder spark ignition engine. Alex. Eng. J. 2018, 57, 2585-2589. [CrossRef]

20. Kumar, K.V.; Puli, R.K.; Kumari, A.S.; Shailesh, P. Performance and emission studies of a SI engine using distilled plastic pyrolysis oil-petrol blends. MATEC Web Conf. 2016, 45, 3002. [CrossRef]

21. Owners Club 206cc P. TU5JP4 Technical Specifications. Peugeot 206cc Owners Club. Available online: http://www.peugeot206cc.co.uk/repair-206/206/info/gb/b1bbmek3.htm (accessed on 1 April 2019).

22. Coates, J. Interpretation of infrared spectra, a practical approach. Encycl. Anal. Chem. 2006, 10815-10837. [CrossRef]

23. OChemOnline. Infrared spectroscopy absorption table. Chem. Libr. 2016, 1-4. Available online: https://chem.libretexts.org/Bookshelves/Ancillary_Materials/Reference/Reference_Tables/Spectroscopic_ Parameters/Infrared_Spectroscopy_Absorption_Table (accessed on 4 September 2020).

24. Shamsul, N.S.; Kamarudin, S.K.; Rahman, N.A. Conversion of bio-oil to bio gasoline via pyrolysis and hydrothermal: A review. Renew. Sustain. Energy Rev. 2017, 80, 538-549. [CrossRef]

25. Martins, J. Motores de Combustão Interna, 6th ed.; Engebook: Porto, Portugal, 2020; p. 586. ISBN 9789898927842.

(C) 2020 by the authors. Licensee MDPI, Basel, Switzerland. This article is an open access article distributed under the terms and conditions of the Creative Commons Attribution (CC BY) license (http://creativecommons.org/licenses/by/4.0/). 